\title{
Reaction of Thiols with formaldehyde in Presnce of succinimid and Reduction of Phenyl Tetrazole Derivative with Hydrogen and Borohydraide
}

\author{
Abdul faris Hussian Hachiam *
}

Received 29, February, 2009

Accepted 10, January, 2010

\begin{abstract}
: is the thiols which used in a wide field in preparation of Mannich bases .

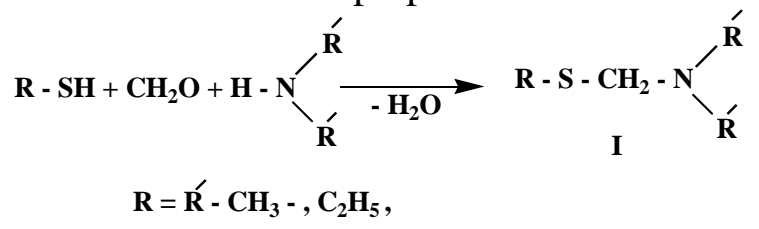

One of most the important compounds which have active hydrogen (substrate)

A large number of Mannich bases have been prepared as a biologically active compound (pharmaceutical, pesticides, bactericidal, fungicidal and tuberculostatic) and in order to correlate their structure and reactivity with their pharmacological activity such as .

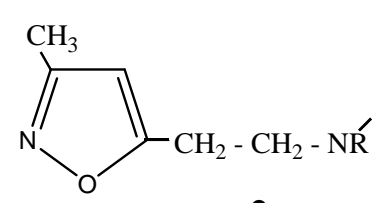

2<smiles>N#CCC1C(=O)ON=C1[AlH2]</smiles>

3

It has been reported that the reaction is easily proceeded by using primary and secondary amine beside formaldehyde. But when we tried the reaction of thiols as substrate and formaldehyde and succinimide instead of amine, the reaction did not proceed to give Mannich base but product were methylenene - bis - sulfide .

$$
2 \mathrm{R}-\mathrm{SH}+\mathrm{CH}_{2} \mathrm{O} \underset{-\mathrm{H}_{2} \mathrm{O}}{\stackrel{\text { SUCCINIMIDE }}{\longrightarrow}} \mathrm{R}-\mathrm{S} \mathrm{CH}_{2}-\mathrm{S}-\mathrm{R}
$$

\section{4}

Mannich base can go farther reaction such as (addition, substitution, cleavge, polymerization, hydrogenation) to produce numerous numberbof compound so we tried to hydrogenation tetrazole derivative which gave different product which depened on type of hydrogen on reagent.

Reduction of 2 - ethyl benzoyle - phenyl tetrazole which performed with hydrogen gas in methanol solution in presence palladium on carbon as catalyst, the tow products were separated by column chromatography.

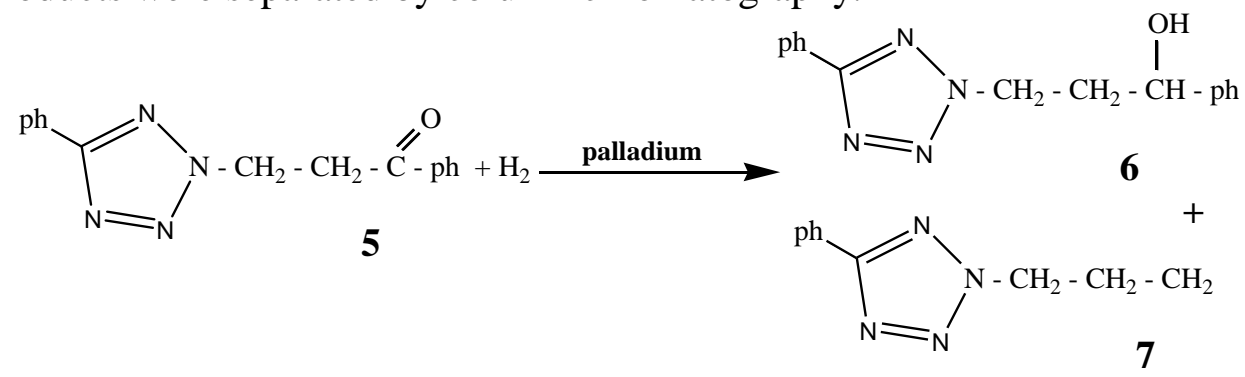

*Department of Basic science, college of Agriculture/ University of Baghdad 
Reduction of 2 -methyl-2 (2-cycloheptane) - 5- phenyl tetrazole.

The methanolic solution the ketone was refluxed with equimolar amount of potassium borohydride and the product is isolated and purified to give.

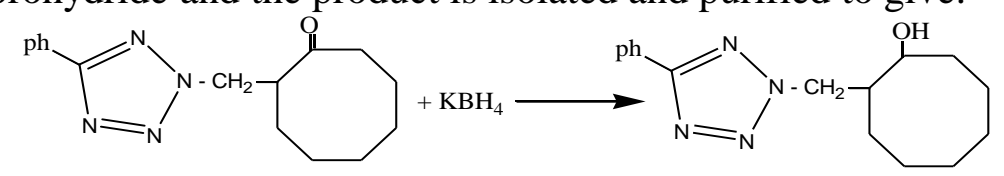

8

9

and identified by C.H.N analysis and NMR spectra.

\section{Key words: Phenyl Tetrazole, Reaction, formaldehyde, Thiols, succinimid}

\section{Introduction:}

Mechanism of Mannich reaction :

The mechanism of Mannich reaction has been well investigated in different $\mathrm{pH}$ media, because the reaction can be carried out in basic or acidic

condition and the used substrate and the amine reactant decide what condition is preferred.

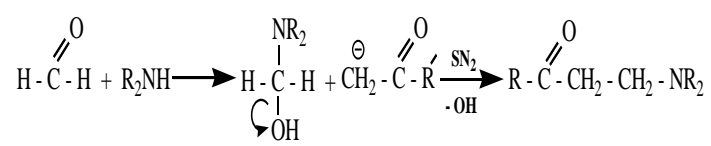

\section{Base - catalyzed reaction:}

The base - catalyzed reaction appears to involve the reaction of a carbanion (derived from the active hydrogen compound) with the aminomethylol by an $\mathrm{SN}_{2}$ mechanism. The rate increase at higher $\mathrm{pH}-$ value.

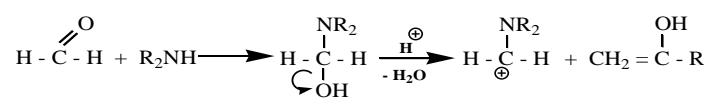

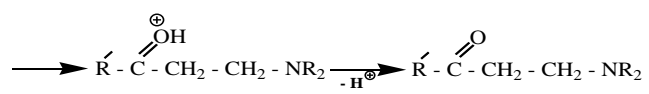

The reaction in acid media appears to involve the reaction of carbonium ion (derived from aminomethylol) with the active hydrogen compound. The rate is slower than for the reaction in basic media and is independent of $\mathrm{pH}$ at low $\mathrm{pH}$ values.

It has been reported than various thiophenols were used as the substrate in $\mathrm{S}-$ aminomethlation rection carried out with ammonia and the primary or secondary and tertiary Mannich bases (10).

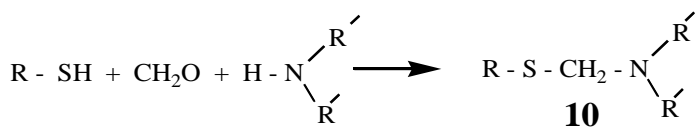

the most frequenthyl used for the reaction were thiophenole and thionaphthol derivative [ 1,2] .

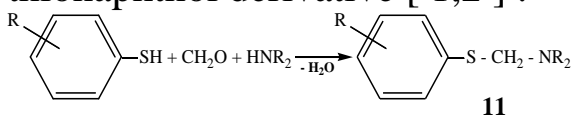<smiles>CCOc1ccc2cc(-c3ccc(Nc4ccc5ccccc5c4)cc3)ccc2c1</smiles>

Similar results were obtained with thiols. The Mannich bases were usually prepared by refluxing a mixture of thiols with formaldehyde and secondary amines for $30 \mathrm{~min}$. secondary amine and formaldehyde in methanol yielding Benzylthiols (methylene -N-dyaikyl ) Thiol.[3,4 ].<smiles>[R]c1cc(S[131I])cc(C)c1O</smiles>

An attempted synthesis of Mannich bases from thiols, formaldehyde and secondary amine we found the reaction give methylene bis - sulfide instead of Mannich bases. 


$$
\begin{aligned}
& 2 \mathrm{R}-\mathrm{SH}+\mathrm{CH}_{2} \mathrm{O} \underset{-\mathrm{H}_{2} \mathrm{O}}{\stackrel{\text { succide }}{\longrightarrow}} \mathrm{R}-\mathrm{S}-\mathrm{CH}_{2}-\mathrm{S}-\mathrm{R} \\
& 14 \\
& 2 \mathrm{ph}-\mathrm{CH}_{2}-\mathrm{SH}+\mathrm{CH}_{2} \mathrm{O} \underset{-}{\stackrel{\text { succinimide }}{\longrightarrow}} \mathrm{ph}-\mathrm{CH}_{2} \mathrm{O}-\mathrm{S}-\mathrm{R} \\
& 15
\end{aligned}
$$

The know procedure for ethylene - bis phenyl sulfide prepration involve reaction of methylene chloride with reaction of thiol and formaldehyde.

According to the literature strong acid of hydrochloric acid is recommended and the mechanism of the reaction with succinimide is different. Here also a primary Mannich base formed from the thiol, formaldehyde and succinimide can react with excess of the thiol yielding the methylene - bis - sulfide $[5,6,7,8]$.

\section{Material; and Methods}

1- Preparation of methylene - bis sulfide

General procedure for the reaction of thiols with formaldehyde in presence of succinimide. 0.08 mole of formaldehyde and 0.08 mole of succinimide or meyhylacetamide were suspended in $50 \mathrm{ml}$ of appropriate thiols. The mixture refluxed for 10 hours, the excess of thiols was evaporated under reduced pressure to dryness. The residue was purified and ecrystillized with hexane.

\begin{tabular}{|c|c|c|c|c|c|c|c|c|}
\hline \multirow{2}{*}{ No. } & \multirow{2}{*}{ Molecular formula } & \multirow{2}{*}{$R$} & \multirow{2}{*}{ Yield } & \multirow{2}{*}{$m \cdot p^{\circ} c$} & & \multicolumn{2}{|c|}{ analysis } & \multirow{2}{*}{$\begin{array}{c}\mathrm{HNMR} \mathrm{CoCl}_{3} \\
\text { S(ppm) }\end{array}$} \\
\hline & & & & & & $C$ & $H$ & \\
\hline 1 & $\mathrm{C}_{15} \mathrm{H}_{16} \mathrm{~S}_{2}$ & $\mathrm{C}_{6} \mathrm{H}_{5} \mathrm{CH}_{2-}$ & 87 & 53 & $\begin{array}{l}\text { calc } \\
\text { foun }\end{array}$ & $\begin{array}{l}69.23 \\
69.16\end{array}$ & $\begin{array}{l}6.15 \\
6.31\end{array}$ & $\begin{array}{c}3.39(\mathrm{~S}, 2 \mathrm{H}) \\
3.66(\mathrm{~S} 4 \mathrm{H}) \\
7.26-7.3(\mathrm{~m}, 10 \mathrm{H})\end{array}$ \\
\hline 2 & $\mathrm{C}_{13} \mathrm{H}_{12} \mathrm{~S}_{2}$ & $\mathrm{C}_{6} \mathrm{H}_{5^{-}}$ & 72 & 40 & $\begin{array}{l}\text { calc } \\
\text { foun }\end{array}$ & $\begin{array}{l}67.24 \\
67.46\end{array}$ & $\begin{array}{l}5.10 \\
5.26\end{array}$ & $\begin{array}{c}4.34(\mathrm{~S}, 2 \mathrm{H}) \\
7.23(\mathrm{~m}, 10 \mathrm{H})\end{array}$ \\
\hline
\end{tabular}

\section{Results:}

$2 \mathrm{R}-\mathrm{SH}+\mathrm{CH}_{2} \mathrm{O} \underset{-\mathrm{H}_{2} \mathrm{O}}{\stackrel{\text { succinimide }}{\longrightarrow}} \mathrm{R}-\mathrm{S}-\mathrm{CH}_{2}-\mathrm{S}-\mathrm{R}$
$\mathbf{1 6}$

Table 1:Yield and properties to the synthesized methylene - bis - sulfide (16)

2- Reduction of 2 - ethylbenzoyl - S phenyltetrazole:

3- It has been reported in literature that two types of product can be formed by readuction of ketonic Mannch bases with different types of reducing agent - besides the usual regent (hydrogen and catalyst, zinc and acid) some novel reducing agent have been recently interduced including the chloride in an acidic medium, some borohydride and tri - butyltin hydride $[9,10,11,12]$.

Excellent results were obtained by using sodium borohydride in alcohol as a reducing agent. Thus $2-$ primary and secondary ethylaryl ketone were converted into the corresponding $\beta$ - aminoalcohols by sodium borohydride (17).

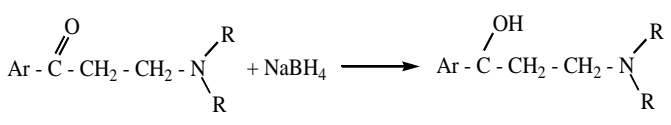

17

In sone cases, 2 aminoethylaryl ketone can be reduced to corresponding $1-$ amino $-3-$ arylpropanol by using Linthium alanate [10]. (18).<smiles>[R]N([R])CCC(O)[Al]CC#CCC(=O)[Al]</smiles>

18

The same results was obtained by using acatalytic hydrogenation of the aminoethyl ketone. The reduction of acetylenic Mannich bases displays several intresting aspect. Thus the triple bond can be only partially hydrogenated with diisobutyl 
aluminum hydride yielding allyamine $[13,14,15]$.

If reduction of acetylenic Mannich bases methyliodide carried out with a metal hydride an alien is produced (19).

$\mathrm{R}-\mathrm{C} \equiv \mathrm{C}-\mathrm{CH}_{2}-\mathrm{N}_{\mathrm{R}}^{\mathrm{R}} \frac{\text { diisobulyl aluminim }}{\text { hydride }} \mathrm{R}-\mathrm{CH}=\mathrm{C}-\mathrm{CH}_{2}-\mathrm{N}_{\mathrm{R}}$

19

The reduction of $2-$ ethylbenzoyl -5 phenyl tetrazole [16 , 17] which performed in methanol solution in the presence of palladium on carbon as a catalyst. The mixture was shacked under 40 ps hydrogen pressure for $6 \mathrm{hrs}$. The resultant reaction mixture showed two product on TLC - plate. After separation by Colum chromatography the product were defined.

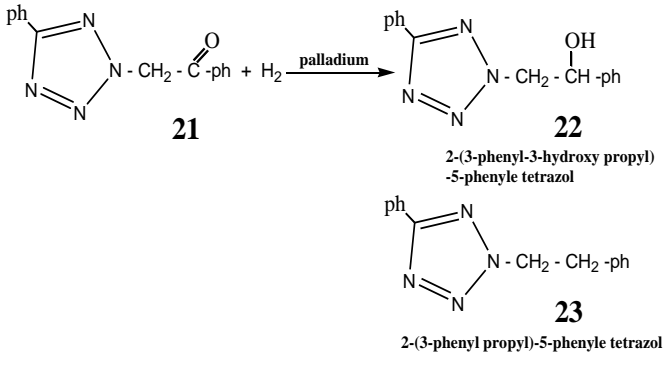

The two product were separated by Colum chrotography.

Elental analysis and NMR spectra for the two products of reduction of (21)<smiles>[R]Cn1nnc(-c2ccccc2)n1</smiles>

Table 1: Yield and properties the product methl [(2-y) cyclohexane]-5-phenyl tetrazole.

\begin{tabular}{|c|c|c|c|c|c|c|c|}
\hline \multirow{2}{*}{ No. } & \multirow{2}{*}{ Molecular formula } & \multirow{2}{*}{$\boldsymbol{R}$} & & \multicolumn{3}{|c|}{ analysis } & \multirow{2}{*}{$\begin{array}{c}\mathrm{HNMR} \mathrm{CoCl} l_{3} \\
\mathrm{~S}(\mathrm{ppm})\end{array}$} \\
\hline & & & & $\mathrm{C}$ & $\mathrm{H}$ & $\mathrm{N}$ & \\
\hline 1 & $\mathrm{C}_{16} \mathrm{H}_{16} \mathrm{~N}_{4} \mathrm{O}$ & $\begin{array}{c}\mathrm{OH}^{\mathrm{O}} \\
-\mathrm{CH}-\mathrm{ph}\end{array}$ & $\begin{array}{l}\text { calc. } \\
\text { foun. }\end{array}$ & $\begin{array}{l}68.57 \\
68.12\end{array}$ & $\begin{array}{l}5.71 \\
5.43\end{array}$ & $\begin{array}{l}20.00 \\
19.65\end{array}$ & $\begin{array}{c}1.9(\mathrm{~S}, 1 \mathrm{H}) . \\
2.46(\mathrm{dd}, 2 \mathrm{H}) . \\
4.83-4.93(\mathrm{~m}, 1 \mathrm{H}) . \\
7.2-7.47(\mathrm{~m}, 8 \mathrm{H}) . \\
8.11-8.15(\mathrm{~m}, 2 \mathrm{H}) .\end{array}$ \\
\hline 2 & $\mathrm{C}_{16} \mathrm{H}_{16} \mathrm{~N}_{4}$ & $-\mathrm{IH}_{\mathrm{CH}}^{\mathrm{OH}}$ & $\begin{array}{l}\text { calc. } \\
\text { foun. }\end{array}$ & $\begin{array}{l}67.24 \\
67.46\end{array}$ & $\begin{array}{l}5.10 \\
5.26\end{array}$ & $\begin{array}{l}21.21 \\
21.01\end{array}$ & $\begin{array}{c}2.37-2.42(\mathrm{~m}, 2 \mathrm{H}) . \\
2.71(\mathrm{t}, 2 \mathrm{H}) \mathrm{J}=7.5 \mathrm{H}_{2} \\
4.64(\mathrm{t}, 2 \mathrm{H}) \mathrm{J}=7.5 \\
7.21-7.50(\mathrm{~m}, 8 \mathrm{H}) . \\
8.17-8.19(\mathrm{~m}, 2 \mathrm{H}) .\end{array}$ \\
\hline
\end{tabular}

Reduction of 2 - methyl $(2-\mathrm{y}$ $1-1$ cycloheptanone) -5 phenyltetrazole by potassium borohydride.

An attempted catalytic hydrogenation of $2-$ methyl $(2-y)-1$ - cycloheptanone) - 5 phenyltetrazole. Under the same condition failed. Neither increase of the hydrogen pressure nor extension of the reaction time did not give the positive result. In this case the borohydride reduction was method of choice. The methanolic Solution of the starting ketone was refluxed with equimolar amount of potassium borohydride for eight hours a typical work up the resulting alcohol was obtained. 


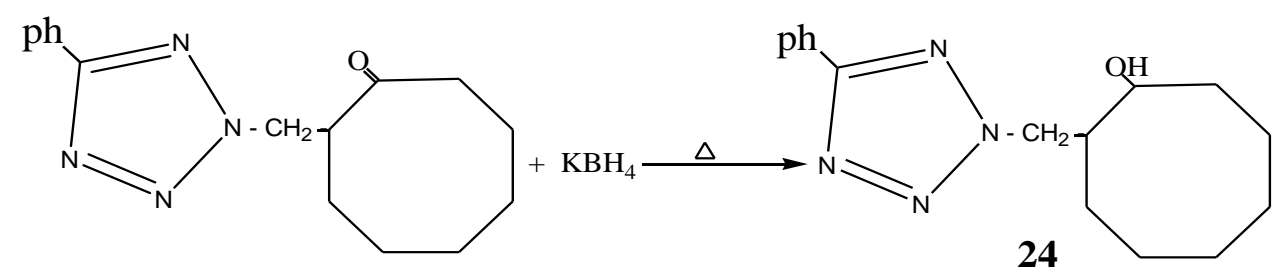

\section{References:}

1. Chowdon,N.S. and Barbas. H. S. 2005. Preparation of Hetrocyclic derivative . Synth . Commune 8(2) : 1207.

2. Chavrell, S; Settimij .S and Novel.H.1961. synthesis of 5substituted Tetrazoles. Formaco Ed. Sci. 16(3): 313.

3. Chao, H.S 1980 .Mechanism of Mannich reaction. Orga , Lett . 7(1): 867-870.

4. Ciranitzer, W. and Stuz. A. 1979. Sulpher containing alkanoic acid derivatives. tetrahedron lett 13(5):3145.

5. Richey, H. G. and Erickson .W.F. 1978. Aminomethylation of five membered aromatic heterocycles compound. Tetrahedron lett .25(4) :1319.

6. Kagon, E. S. and. Mikhailov .V. I. 1979. Sulpher containing alkenyl substituted benzoic acid and phenyl tetrazoles . Chem, abstr. 90(23), 6213.

7. Mitchell, C. E. and Brenner. S. E. 2005. mannich reaction of imidazoles, benzimidazole. chem. commune .9(3): 5346-5368.

8. Pollak, I . E. and Grillat. G. F, J. 1967. Heterocyclic derivative $p$ org. chem.2(6):2891.
9. Rahbek, K. and kunndesen . S. 2001. Mitchell. Structural studies of 2,4-Dimethyl phenyl. chem. commune .2 (2) : 66-86.

10. Vineyard ,B. D. 1966. The Mannich reaction of benzimidazole derivative. J.chem . Eng. Data 11(4) : 620 .

11. Singh, N. and Siinghs .Z . 1969. Indian . Method of preparation of alkylated compound. J. Chem. $16(5): 313$.

12. Sinhababu, A. K. and Borchardt. F. 1983. The introduction of aminomethyl group to oxadiazole. synth. Commune 13 (4) : 677.

13. Stephen, D.P.1988.Ramanthan R. Reaction of hetrocyclic compound. . Phosphorus sulphur 37(12) : 117.

14. Szmuszkovicz, J. J. 1960. Alkylation reaction with Mannich bases.. Am Chem. Soc. 82(12). 1180.

15. Vineyard, B. D. 1966. Organometallic addition reaction. J.chem. Eng. Data 11(5):620.

16. Yamada ,K. Itoh .N.and Iwakuma. I.1978. Preparation and reaction of Mannich bases. J. Chem. Soc .Chem. Commune 12(6) :1089.

17. Yamamato, Y. and Mamiyamak . J. 2004. Reduction and cyclization of heterocyclic compound . Am. Chem. Soc. 126 (12) :5962-93. 


\title{
تفاعل الثايولات مع الفورملدهايد بوجود السكنتامايد واختزال مشتقات الفنيل

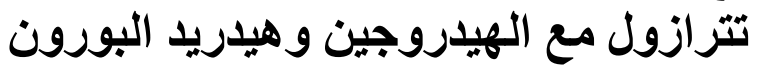

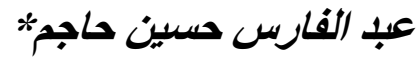

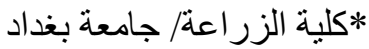

ان المو اد التي تستعمل بوصفها اساسيات و التي تحتوي على هيدروجين فعال في تحضير (قاعدة مـانخ)

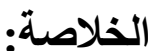

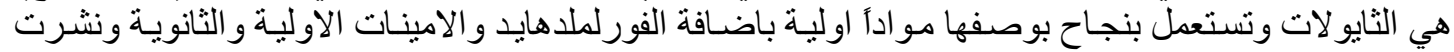

بحوث عديدة في الوقت الحاضر عن هذا الموضوع (25).

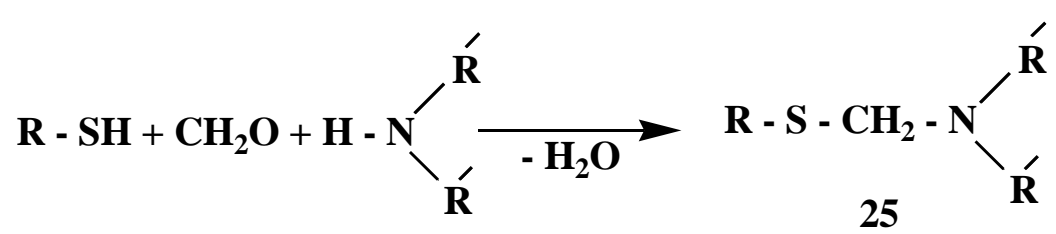

وفي بحثنا هذا عندما اردنـا استعمال الثايول بوصفها مـادة اساسية وباضـافة السكنمايد بدل الامينـات methylenene -

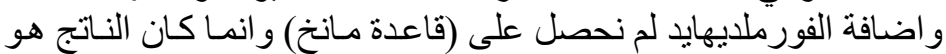

$$
2 \mathrm{R}-\mathrm{SH}+\mathrm{CH}_{2} \mathrm{O} \underset{-\mathrm{H}_{2} \mathrm{O}}{\stackrel{\text { SUCCINIMIDE }}{\longrightarrow}} \mathrm{R}-\mathrm{S} \mathrm{CH}_{2}-\mathrm{S}-\mathrm{R}
$$

.(26) bis - sulfide

\section{6}

ونت تحضير مجمو عة من هذه المشتقات و التأكد منها بإجر اء التحاليل المختلفة.

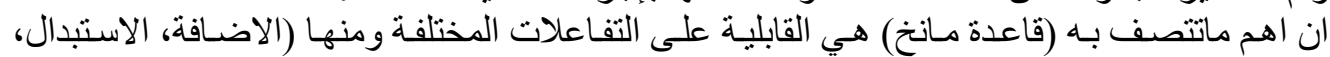

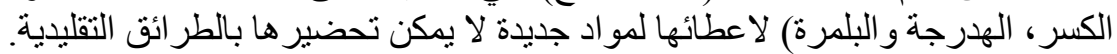

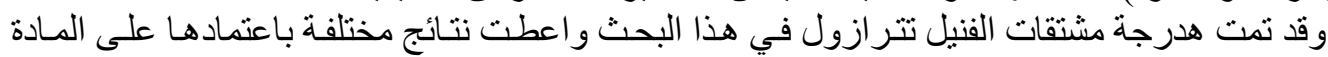

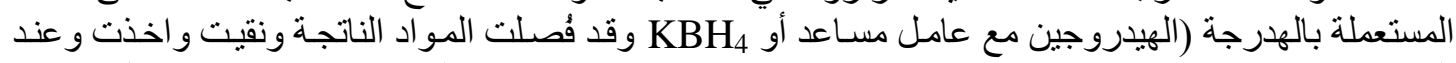

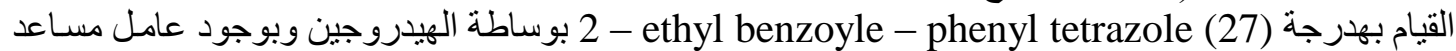
اعطت خليط من مادتين [29, 29,<smiles>CC#CC[C@H](C)C(=O)CCn1nnc(-c2ccccc2)n1</smiles><smiles>OC(CCn1nnc(-c2ccccc2)n1)c1ccccc1</smiles>

27<smiles>CCCn1nnc(-c2ccccc2)n1</smiles>

وتم فصل المادتين بوساطة جهاز Colum chromatography باستخدام السلكاجيل و السلكلو هكسـان

بوصفه مذيباً وتم اجر اء التحاليل اللازمة. وكذللك تمت هدرجة (30) - methylcyclheptan - 1 - one - 5 - phenyltetrazole

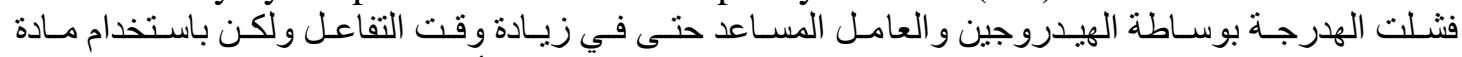

potassium borohydride<smiles>CCCCCCCC1CCCCCC(=O)C1Cn1nnc(-c2ccccc2)n1</smiles>

30<smiles>CCCC1CCCCCCC1O</smiles> 